OPEN ACCESS

Edited by:

Gianluca Piovesan,

University of Tuscia, Italy

Reviewed by:

Gabriel Sangüesa-Barreda,

University of Valladolid, Spain

Parminder Singh Ranhotra,

Birbal Sahni Institute of Palaeobotany,

India

${ }^{*}$ Correspondence:

Olga Solomina

olgasolomina@yandex.ru

Specialty section:

This article was submitted to

Paleoecology,

a section of the journal

Frontiers in Ecology and Evolution

Received: 08 July 2021

Accepted: 09 September 2021

Published: 13 October 2021

Citation:

Solomina O and Matskovsky V (2021) Dendrochronology in European

Russia in the Early 21st Century:

State of the Art.

Front. Ecol. Evol. 9:738199.

doi: 10.3389/fevo.2021.738199

\section{Dendrochronology in European Russia in the Early 21st Century: State of the Art}

\author{
Olga Solomina* and Vladimir Matskovsky \\ Institute of Geography RAS, Moscow, Russia
}

In this review, we have focused on the following key points: (1) living trees in European Russia and their climatic sensitivity. Species suitable for tree-ring analyses, their age limits, spatial distribution of temperature- and drought-sensitive trees, and the available tree-ring chronologies. (2) Extension of the living-tree chronologies using archeological and architectural samples. Dendrochronological dating of archeological and cultural monuments. (3) Tree-ring-based climatic reconstructions in European Russia. European Russia drought atlas. (4) Climatic and environmental reconstructions in the Northern Caucasus. (5) Dendroecology. We also briefly summarized the problems and prospects of tree-ring research in European Russia.

Keywords: tree-ring reconstructions, archeological wood, wood dating, Pinus sylvestris, Picea abies, Quercus robur, East-European plain, Northern Caucasus

\section{INTRODUCTION}

The first tree-ring study in the Russian Empire dates back to 1892 CE, when Shvedov (1892) suggested reconstructing the droughts in Odessa using Acacia sp. ring width. In the Soviet time, the center of tree-ring research in the European part of the Soviet Union was located in the Institute of Botany in Kaunas, Lithuania, led by T. Bitvinskas who edited the first publications of tree-ring-width measurements in the series of books "Dendroscales of the Soviet Union." Most chronologies created for the territory of the European part of the Soviet Union and Russia (e.g., Bitvinskas, 1974; Molchanov, 1976; Lovelius, 1979; Chernavskaya et al., 1996; Pushin et al., 2000; Rumyantsev, 2010; etc.) were and still are usually published in Russian. They were not included in the international databases, not available in the digital form, and, therefore, are rarely used in the global studies. Among rare exceptions is a data set collected along the northern tree line, submitted to the International Tree-Ring Data Bank (ITRDB), and used for the reconstructions of summer temperature in the sub-Arctic regions, including Northern Europe region which covered the north of European Russia, for 950-1960 CE (Schweingruber and Briffa, 1996; Briffa et al., 2001).

Recently, several tree-ring chronologies for European Russia have been included into the ITRDB. They are as follows: 13 chronologies of living trees of pine (Pinus sylvestris), spruce (Picea abies, Picea obovata), and larch (Larix sibirica) (Hughes et al., 2019), two chronologies of oak (Quercus robur) (Khasanov and Sandlersky, 2018), and three chronologies of wood from ancient buildings and archeological materials (Kolchin and Chernykh, 1977; Chernykh and Karpukhin, 2006; Karpukhin et al., 2019). However, even in the 21st century, the space of the European Russia in ITRDB is covered by rare points of tree-ring sites, compared with the nearby regions, 
especially Fennoscandia and Lithuania (Figure 1). Meanwhile, looking at the new European Russia Drought Atlas (Cook et al., 2020) one will see dozens of sites in this area. Thus, a rich data set presented mostly in the Russian literature is hidden behind the empty space at the map. In this paper, we have provided a brief review of the tree-ring studies in European Russia published in the past two decades.

\section{SPECIES, LENGTH OF CHRONOLOGIES, AND CLIMATIC SIGNAL}

European Russia is located within the sub-Arctic and temperate climate zones. It is subdivided into the following vegetation zones: tundra $\left(67^{\circ} \mathrm{N}-70^{\circ} \mathrm{N}\right)$, northern and central taiga $\left(60^{\circ} \mathrm{N}-\right.$ $67^{\circ} \mathrm{N}$ ), southern taiga and mixed forests $\left(56^{\circ} \mathrm{N}-60^{\circ} \mathrm{N}\right)$, broadleaved forests $\left(53^{\circ} \mathrm{N}-56^{\circ} \mathrm{N}\right)$, forest-steppe $\left(53^{\circ} \mathrm{N}-54^{\circ} \mathrm{N}\right)$, and steppe (south to $53^{\circ} \mathrm{N}$ ). Khibiny (up to $1,200 \mathrm{~m}$ a.s.l.), Carpathians (up to 2,655 m a.s.l.), Caucasus (up to 5,642 m a.s.l.), and Urals (up to $1,895 \mathrm{~m}$ a.s.l.) mountains are bordering the East European plain from the north-west, west, south, and east, respectively. The central and southern regions of the East European plain were traditionally used for agriculture; therefore, the original vegetation is poorly preserved in these areas, especially in the forest-steppe ecotone. In the northern part of the plain only small fractions of undisturbed forests are left due to extensive logging.

The average and maximum length of the sampled tree-ring series are as follows: 171 and 534 years for pine, 137 and 499 years for spruce, 193 and 413 years for larch, 116 and 277 years for oak. Long-living trees are unique and are preserved only in the protected areas such as national parks or by the cemeteries, monasteries, and other sacred places. The livingtree chronologies extend back to the 15-16th centuries in the northern regions [e.g., Solovetsky archipelago (Solomina et al., 2011; Dolgova et al., 2019), Keretsky archipelago (Tishin and Chizhikova, 2011), Arkhangelskaya region (sites from ITRDB; Schweingruber and Briffa, 1996), Murmansk region (Shumilov et al., 2011), and in the mountain areas, namely, in Khibiny (Kononov et al., 2009) and in the Northern Caucasus (Dolgova, 2016)]. In the central and southern parts of the plain they usually do not exceed 200-300 years [e.g., Optina Pustin': 17172010 CE, Zvenigorod: 1763-2014 CE (Solomina et al., 2017), Raifa forest: 1714-2014 CE (Tishin, 2006; Kuznetsova, 2020), Morozovskaya forest: 1741-2014 CE (Matskovsky et al., 2016b; Matveev et al., 2019)]. Tishin (2006) developed 70 tree-ring chronologies for different species in the Middle Volga region $\left(56.6^{\circ} \mathrm{N} 47.8^{\circ} \mathrm{E}-54.4^{\circ} \mathrm{N} 51.8^{\circ} \mathrm{E}\right)$, including pine (P. sylvestris), spruce [Picea fennica (Regel) Kom.], oak (Q. robur), and linden (Tilia cordata Mill.), the longest chronologies starting in 1850 CE. Forbes et al. (2010) showed high dendroclimatic potential of the shrub Salix lanata L. in the European Russian Arctic (Nenets Autonomous Okrug).

At the moment, we estimate the number of verified highquality living-tree ring-width chronologies in European Russia as approaching to 300 sites (e.g., Tishin, 2006; Solomina et al., 2017; Cook et al., 2020). Seventy tree-ring-width chronologies from this area will be released to the ITRDB in 2021 (the publication by Solomina and coauthors is to be submitted to Scientific Data journal).

In most sites, the trees growing in the East European plain show a moderate to low sensitivity to climate (correlation coefficients rarely exceed 0.5 ) and a mixed climatic signal, except for the northern and southern tree lines (Bitvinskas, 1974; Molchanov, 1976; Graybill and Shiyatov, 1988; Lopatin et al., 2007; Hughes et al., 2019). The analysis of the correlation coefficients of the chronologies with monthly and seasonal and cumulative climatic parameters acquired from the daily meteorological data allowed to identify the boundary between temperature-sensitive and drought-sensitive trees at about $55^{\circ} \mathrm{N}-$ $60^{\circ} \mathrm{N}$ (Matskovsky, 2013, 2016). The radius of significant correlation between tree-ring-width chronologies decreases from about $1,000-1,500 \mathrm{~km}$ in the north to $500 \mathrm{~km}$ and less in the center of the plain (Matskovsky, 2013).

\section{EXTENSION OF CHRONOLOGIES BACK IN TIME, DATING}

The first long chronology in European Russia was constructed in Novgorod from the Medival wooden pavements from archeological excavations (Kolchin, 1962; Kolchin and Chernykh, 1977). In the recent decades, the chronology was supplemented with the new samples and verified with the Finnish chronology (Tarabardina, 2009). The excavations continue and the chronology is being enriched with the new material (Tarabardina et al., 2016; Petrov and Tarabardina, 2020). So far, it is not connected with the regional livingtree chronologies and is used exclusively for the dating of archeological artifacts, except for one study (Helama et al., 2017), which used these data to make a temperature reconstruction for 1160-1416 CE.

In Karpukhin (2009) one can find a map and the description of 17 archeological tree-ring chronologies for European Russia. Unfortunately, most of those chronologies were not verified by crossdating with living trees. Moreover, they contain measurements made manually, that have not been checked by COFECHA crossdating or skeleton plots. Therefore, they were not used so far for paleoclimatic purposes.

The one exception is the chronology based on the archeological and architectural wood from the Vologda region (from 1085 to $2020 \mathrm{CE}$ ), that was recently connected to living trees, revised, and verified by Karpukhin and Matskovsky (2014). So far, it is the longest continuous chronology in the East European plain.

Another long conifer chronology covering the period from $1183 \mathrm{CE}$ was constructed from living pine and spruce trees and extended with wooden samples from the Solovetsky Monastery that was founded in 1436 CE (Solomina et al., 2011; Matskovsky et al., 2013). Other composite chronologies that include archeological and architectural samples are from Smolensk (353 years), Kostroma (534 years), Volga (478 years), and Arkhangelsk (646 years) regions (Solomina et al., 2017; Figure 2). 


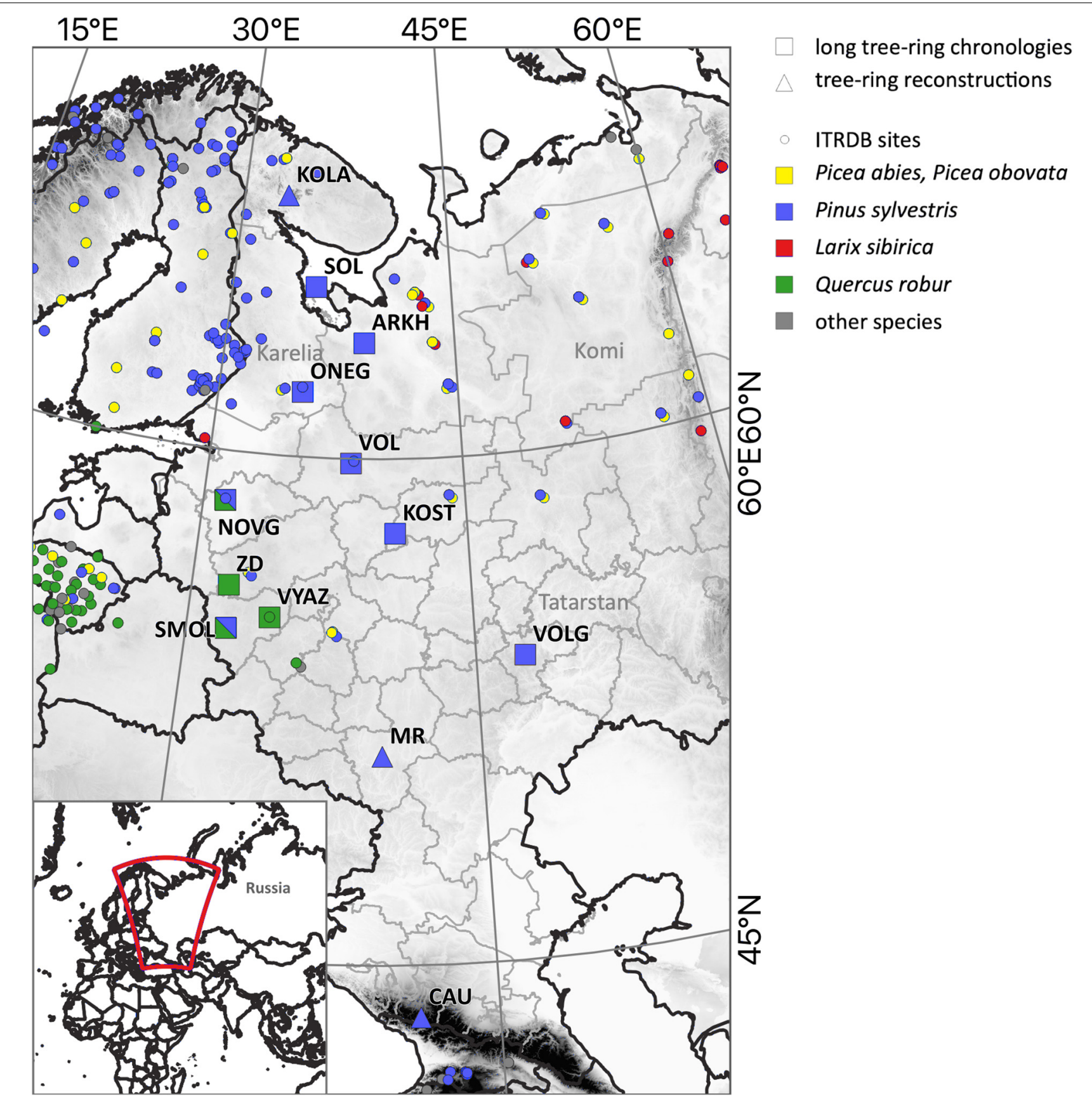

FIGURE 1 | Location of the tree-ring sites in European Russia. KOLA-summer temperature reconstruction (1600-2004, Kononov et al., 2009), MR-SPEI reconstruction (1790-2014, Matskovsky et al., 2016b), CAU-summer temperature reconstruction (1596-2011, Dolgova, 2016). Long tree-ring chronologies are described in Figure 2. Grayscale shading shows elevation.

Three oak chronologies were built with subfossil oak wood excavated from the alluvial deposits of the Zapadnaya Dvina (Daugava) River (649-1382 CE) and the archeological samples from Novgorod (1059-1386 CE) and Vyazma (1074-1306 CE). They have been matched with the chronologies from Polotsk (Republic of Belarus) and from Eastern Europe, as well as dated by radiocarbon (Karpukhin et al., 2020; Khasanov et al., 2021a). Another part of the Zapadnaya Dvina chronology (1346-1762
CE) is to be published soon (Khasanov et al., 2021b). Sochová et al. (2021) recently published a review of oak dendrochronology in Eastern Europe, including Western Russia.

Using the above-mentioned long chronologies, and also those from Belarus (Yermokhin, 2012), a number of unique monuments were dated, such as the Landskrona Fortress in St. Petersburg (1300 CE, unpublished), the chapel of Cyril (1510s CE, rebuilt in $1557 \mathrm{CE}$ ) and the Church of the Ordination (1778 


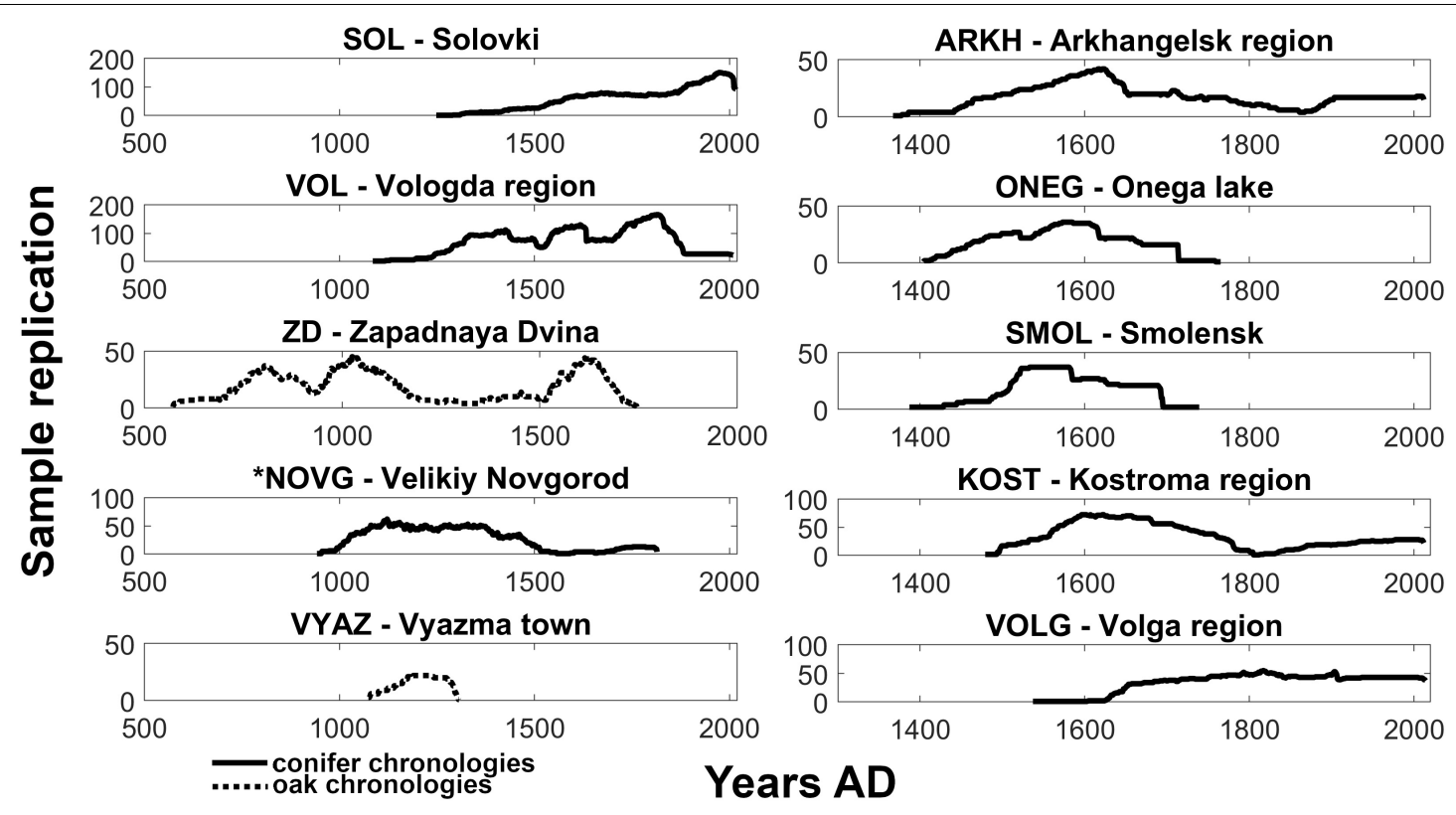

FIGURE 2 | Replication of long chronologies in European Russia. Note different axes. For the locations see Figure 1. *Higher length and replication are reported by Tarabardina et al. (2016): 9th-19th centuries, 6,505 dated samples in total.

CE) in the Cyril-Belozersky monastery (Matskovsky, 2014), the Church of St. Andrew on the Zayatsky Island of the Solovetsky Archipelago (1699 CE, Matskovsky et al., 2013), a number of wooden churches around Onega lake (Karpukhin et al., 2019) and Arkhangelsk region. The Vologda chronology was used for the dating of several medieval icons, including Novgorod icon "The Mother of God Dexiocratussa” (1410 CE) (Voronin et al., 2015; Matskovsky et al., 2016a; Dolgikh et al., 2017).

In Figures 1, 2, we summarize our knowledge on the wellmeasured (semiautomatic devices like Rinntech and Velmex, CooRecorder program) and well-dated (TSAPWin, CDendro, controlled by COFECHA, based on crossdating with living trees or other well-dated chronologies) long tree-ring-width chronologies in European Russia.

\section{TREE-RING-BASED CLIMATIC RECONSTRUCTIONS IN EUROPEAN RUSSIA}

Ring-width and density chronologies of conifers from temperature-sensitive sites in the northern part of the East European plain (e.g., Schweingruber and Briffa, 1996) were used in a regional part of Circum-Arctic temperature reconstruction (Briffa et al., 2001, 2002), but are normally not included into global reconstructions (e.g., Ljungqvist et al., 2012; PAGES 2k Consortium, 2013; Luterbacher et al., 2016; etc.) due to their comparatively short lengths. Additionally, most chronologies submitted to the ITRDB from these regions finish in 1990s and, hence, they are missing the past two to three decades of records.

A 561-year long pine tree-ring width chronology from the northern tree line (Murmansk region) was used to assess the effects of volcanic and solar forcings on tree growth (Shumilov et al., 2011; Kasatkina et al., 2013, 2019). Khasanov (2011, 2013) showed that wood anatomy of oaks may be specifically affected by severe winters, or winter and spring weather anomalies, and reconstructed these anomalies since $1826 \mathrm{CE}$. Drought-sensitive chronologies in the European Russia were reported for the middle Volga area (Tishin, 2006; Solomina et al., 2017; Kuznetsova, 2020) and Voronezh region (Matskovsky et al., 2016b). Using eight pine ring-width chronologies Kuznetsova (2020) demonstrated the increase in climate sensitivity of pine from the N-W to S-E $\left(57^{\circ} \mathrm{N}, 47^{\circ} \mathrm{E}\right.$ to $\left.53^{\circ} \mathrm{N}, 52^{\circ} \mathrm{E}\right)$ due to the increase in continentality in the same direction. She reconstructed the June-September self-calibrated Palmer drought severity index (scPDSI) for 1825$2013 \mathrm{CE}$ as well as the river runoff in this area. According to this reconstruction, the drought frequency in the second half of 20th and early 21st centuries increased in comparison with the earlier period. Matskovsky et al. (2016b) used the pine drought-sensitive chronology (Matveev et al., 2012, 2019) to reconstruct the SPEI index in June since 1790s. They speculated that prolonged drought in 1890s had led to the agricultural crisis in Central Russia that affected the social stability and was one of the drivers of the revolutions that occurred in 1905 and 1917.

Recently, the chronologies from the East European plain and adjacent regions were used to create the European Russia Drought Atlas, a half-degree gridded reconstruction of summer scPDSI for 1400-2016 CE (Cook et al., 2020). Three principal modes of hydroclimatic variability in the European Russia were identified and the drought frequency and intensity over this period were assessed. Despite this obvious progress, more drought-sensitive chronologies are required to better constrain and verify the model, especially in the early period of the reconstruction. 


\section{CLIMATIC AND ENVIRONMENTAL RECONSTRUCTIONS IN THE NORTHERN CAUCASUS}

The Caucasus is a high mountain system located around the $43^{\circ} \mathrm{N}$. It is the first barrier for the cold air masses occasionally moving southward from the Arctic. Therefore, the climate in the Northern Caucasus is more severe than at its southern slope, but it is still temperate, and relatively mild. The steppe vegetation rises up to $700 \mathrm{~m}$ a.s.l., while the forests dominated by oak, beech, spruce, and pine in the Northern Caucasus are located in more humid habitats up to $2,700 \mathrm{~m}$ a.s.l. At the upper tree limit, the most common species are pine, birch, juniper, and beech.

Due to rather favorable climatic conditions, a weak and mixed climatic signal in the ring-width chronologies in the Caucasus was observed (Turmanina, 1971, 1988; Solomina, 1999; Grabenko and Solomina, 2018).

At the moment, about 50 chronologies of pine (P. sylvestris), fir (Abies nordmanniana), oak (Quercus petraea), and beech (Fagus orientalis) covering the Northern Caucasus from Adygeya in the west to Osetia in the east $\left(40^{\circ} \mathrm{N}-43^{\circ} \mathrm{N}, 41^{\circ} \mathrm{N}-43^{\circ} \mathrm{E}\right)$ reach as far back as the mid-15th century CE (Solomina et al., 2012, 2016; Dolgova, 2016). Several dead wood collections were also assembled, but they did not extend the living-tree chronologies beyond the 15th century. Matskovsky et al. (2019) combined the tree-ring methodology with the ${ }^{14} \mathrm{C}$ dating and dated the beams of the ancient buildings in Ingushetia of 10-11th, 14-17th, and 19th centuries CE this way.

The first reliable temperature reconstructions based on tree rings of pine and fir growing in the vicinity of the upper tree line was based on the minimum Blue Intensity (BI, Dolgova, 2016). The summer of $1596 \mathrm{CE}$ was the coldest in the records (3.6 ${ }^{\circ} \mathrm{C}$ colder than the mean in 1961-1990 CE), whereas the 2010 CE summer was the warmest one exceeding the 19611990 mean by $+3.6^{\circ} \mathrm{C}$. The reconstruction is representative for the neighboring areas $\left(30^{\circ} \mathrm{N}-50^{\circ} \mathrm{N}, 25^{\circ} \mathrm{E}-55^{\circ} \mathrm{E}\right)$ and the multidecadal band width correlates with the reconstruction of June-August temperature in the Central Europe by Büntgen et al. (2011). Holobâcă et al. (2016) also reconstructed summer temperature in the Northern Caucasus since $1830 \mathrm{CE}$ but used a less sensitive ring-width proxy. The combination of ring width and density also allowed the reconstruction of Garabashi glacier mass balance (Dolgova et al., 2013).

Tree rings were used to identify the minimum limiting age of the Little Ice Age moraines at a number of glaciers, where the timberline rises high enough and approaches the glacier fronts (e.g., Bolshoy, Azau, Kashkatash, Terskol, and Tsey) (Bushueva and Solomina, 2012; Bushueva et al., 2016; Solomina et al., 2016, 2021).

\section{DENDROECOLOGY}

The dendroecological studies in European Russia are neither systematic nor numerous. A few papers discuss the cambium activity, xylogenesis, and seasonal growth of pine in the central and northern parts of the region (Tishin et al., 2016, 2019;
Matveev et al., 2020). The negative influence of recreational activity on pine growth in the Kursk region was studied by Evdokimova et al. (2020). Since 1978's Matveev with coauthors (Matveev and Akulov, 2012; Matveev and Lykov, 2019) have been monitoring the influence of suburban highways on pine growth in Voronezh region. Lopatin et al. (2008) assessed the long-term growth trends of spruce and pine forests in the Komi republic $\left(49^{\circ} \mathrm{E}-57^{\circ} \mathrm{E}, 60^{\circ} \mathrm{N}-67^{\circ} \mathrm{N}\right)$, identified positive trends throughout the 20th century in all the studied forest subzones within this area, and discussed the possible role of temperature as the main driving factor. Dendrochronological methods were also used to assess the forest productivity (Baibar and Kharitonova, 2017; Dyakonov et al., 2017) and historical patterns of natural disturbance regimes (Khakimulina et al., 2016; Kilpinen, 2018) in boreal forests. Aakala et al. (2011) identified droughts and bark beetles to be driving the forest dynamics in the past 200 years in the Arkhangelsk region. Several studies were focused on the forest fire reconstructions (Drobyshev and Niklasson, 2004; Kharitonova and Novenko, 2019; Mergelov et al., 2020; Ryzhkova et al., 2020). Lange et al. (2018) found that in Scots pine ring-width and density chronologies at northern sites microsite differences affect the absolute tree growth, but play a minor role for the summer temperature signal. Tishin et al. (2018) studied the adaptation of introduced species like the Manchurian walnut (Juglans mandshurica) and the Amur cork tree (Phellodendron amurense) in the Middle Volga region to the environmental and climatic conditions.

\section{PROBLEMS AND PROSPECTS}

The main limitation for the development of dendroclimatic research in the East European plain is the lack of long-living trees. Still the potential to find suitable sites and to use the old wood from architectural and archeological sites is far from being exhausted. Many floating chronologies stored in the archeological archives are not yet connected to the living-tree chronologies. Unfortunately, the wood itself is rarely preserved after processing. Most of the measurements performed in European Russia before 2000s without semiautomatic devices like Lintab or Velmex contain many errors, and the original wood is lost forever. Finally, only few long chronologies that are connected to the living trees are suitable for paleoclimatic research.

For paleoclimatological applications, the problem of weak and mixed signal in ring width of trees growing in most habitats in the central part of European Russia and in the Caucasus can be partly overcome by the use of other tree-ring parameters, such as the maximum latewood density. Its surrogate, BI, was successfully used for the crossdating of samples (Semenyak et al., 2021) and the summer temperature reconstruction in the Caucasus (Dolgova, 2016) and in the Kaluga region (Solomina et al., 2017). Stable carbon isotopes in tree rings proved to be a good proxy for drought reconstructions both in living trees (Brugnoli et al., 2010) and in archeological wood (Panyushkina et al., 2016), but they are still rarely used in European Russia. A promising potential to find subfossil wood in the lakes, peats, rivers, and at the Arctic coast is still almost not explored. 
The dendroecological studies focused on the history of forest stands, fire regimes, disturbances, growth dynamics of introduced species, etc., are still very rare in European Russia. Meanwhile, they could help to solve important ecological problems that are valuable for the society. For instance, in the last two decades, a quarter of the conifer forests in the nearMoscow region dried out due to the outbreaks of the bark beetles and climate change. The whole population of boxwood (Buxus colchica) in the Krasnodar region was exterminated by insects (Pyralidae sp.), introduced to Russia together with Italian plants in 2012 CE. What is the contribution of insect outbreaks, climate change, and forest management? Dendroecology can address these complex problems and even suggest possible solutions.

\section{AUTHOR CONTRIBUTIONS}

OS and VM searched and reviewed the literature, provided critical feedback, and helped to shape the manuscript. OS took the lead in writing the manuscript with inputs from

\section{REFERENCES}

Aakala, T., Kuuluvainen, T., Wallenius, T., and Kauhanen, H. (2011). Tree mortality episodes in the intact Picea abies-dominated taiga in the Arkhangelsk region of northern European Russia. J. Veget. Sci. 22, 322-333. doi: 10.1111/j. 1654-1103.2010.01253.x

Baibar, A. S., and Kharitonova, T. I. (2017). "Methodological approaches to assessing the productivity of forest ecosystems (on the example of landscapes of the central forest state natural biosphere reserve) (Metodicheskiye podkhody $\mathrm{k}$ otsenke produktivnosti lesnykh ekosistem (na primere landshaftov tsentral'nolesnogo gosudarstvennogo prirodnogo biosfernogo zapovednika)," in Landscape science: theory, methods, landscape and ecological support of nature management and sustainable development (Landshaftovedeniye: teoriya, metody, landshaftno-ekologicheskoye obespecheniye prirodopol'zovaniya $i$ ustoychivogo razvitiya), eds K. A. Merkalova, et al. (Tumen: TyumGU), 64-67.

Bitvinskas, T. T. (1974). Dendroclimatic investigations (Dendroklimaticheskie issledovaniia). Leningrad: Gidrometoizdat.

Briffa, K., Osborn, T., Schweingruber, F., Harris, I. C., Jones, P. D., Shiyatov, S. G., et al. (2001). Low frequency temperature variations from a northern tree-ring density network. J. Geophys. Res. 106, 2929-2941. doi: 10.1029/2000JD900617

Briffa, K. R., Osborn, T. J., Schweingruber, F. H., Jones, P. D., Shiyatov, S. G., and Vaganov, E. A. (2002). Tree-ring width and density data around the Northern Hemisphere: part 1, local and regional climate signals. Holocene 12, 737-757. doi: 10.1191/0959683602hl587rp

Brugnoli, E., Solomina, O., Spaccino, L., and Dologova, E. (2010). Climate Signal in the Ring Width, Density and Carbon Stable Isotopes in Pine (Pinus silvestris L.) in Central Caucasus. Geogr. Environ. Sustain. 4, 4-16. doi: 10.24057/20719388-2010-3-4-4-16

Büntgen, U., Tegel, W., Nicolussi, K., McCormick, M., Frank, D., Trouet, V., et al. (2011). 2500 years of European climate variability and human susceptibility. Science 331, 578-582. doi: 10.1126/science.1197175

Bushueva, I. S., and Solomina, O. N. (2012). Fluctuations of Kashkatash glacier in XVII-XXI by carthographic, dendrochronological and lichenonemtric data. Ice and Snow 2, 121-130. doi: 10.15356/2076-6734-2012-2-121-130

Bushueva, I. S., Solomina, O. N., and Volodicheva, N. A. (2016). Fluctuations of Terskol glacier, Northern Caucasus, Russia. Earths Cryosphere 3, 95-104.

Chernavskaya, M. M., Pushin, A. V., and Zemtsov, D. Y. (1996). Growth response to circulationprocesses over the North-Western part of the Russian Plane. Dendrochronologia 14, 181-191.

Chernykh, N. B., and Karpukhin, A. A. (2006). Some results of a dendrochronological study of wood in the Church of Elijah the Prophet in the Tsypin churchyard (Vologda region, Kirillovsky district). (Nekotoryye
VM. Both authors contributed to the article and approved the submitted version.

\section{FUNDING}

This study was supported by the Russian Science Foundation grant no. 21-17-00264 (European Russia part) and by the State assignment project no. 0148-2019-0004 (Northern Caucasus part). It was conducted in the laboratory created by the Megagrant project (agreement no. 075-15-2021-599, 08.06.2021).

\section{ACKNOWLEDGMENTS}

The authors would like to thank Irina Bushueva for the cartographic support and Mikhail Alexandrin for language correction. The authors would also like to thank two reviewers for their comments.

rezul'taty dendrokhronologicheskogo izucheniya drevesiny tserkvi Il'i Proroka v Tsypinskom pogoste (Vologodskaya obl., Kirillovskiy r-n). KSIA 220, 127-134.

Cook, E. R., Solomina, O., Matskovsky, V., Cook, B. I., Agafonov, L., Berdnikova, A., et al. (2020). The European Russia Drought Atlas (1400-2016 CE). Clim. Dyn. 54, 2317-2335. doi: 10.1007/s00382-019-05115-2

Dolgikh, A. V., Matskovsky, V. V., Voronin, K. V., and Solomina, O. N. (2017). Combined Dendrochronological and Radiocarbon Dating of Six Russian Icons from the 15th-17th Centuries. Dokl. Earth Sci. 474, 706-708. doi: 10.1134/ S1028334X17060186

Dolgova, E. (2016). June-September temperature reconstruction in the Northern Caucasus based on blue intensity data. Dendrochronologia 39, 17-23. doi: 10.1016/j.dendro.2016.03.002

Dolgova, E. A., Solomina, O. N., Matskovsky, V. V., Dobryansky, A. S., Semenyak, N. A., and Shpunt, S. S. (2019). Spatial variability of pine growth in the Solovetsky Islands. Izvestiya of the Academy of Sciences. Geogr. Ser. 2, 41-50. doi: 10.31857/S2587-55662019241-50

Dolgova, EA, Matskovsky, V. V., Solomina, ON., Rototaeva, OV., Nosenko, G. A, and Khmelevskoy, I. F. (2013). Mass balance reconstruction of Garabashi glacier (1800-2005) by tree-ring data. Ice and Snow 1, 34-42.

Drobyshev, I., and Niklasson, M. (2004). Linking tree rings, summer aridity, and regional fire data: an example from the boreal forests of the Komi Republic, East European Russia. Can. J. For. Res. 34, 2327-2339. doi: 10.1139/x04-112

Dyakonov, K. N., Bajbar, A. S., and Kharitonova, T. I. (2017). Interdecadal dynamics of the efficiency of photosynthetically active radiation utilization in the forests of Meshhera. Vestnik Moskovskogo Univ. Seriya 5 Geografiya 5, $12-23$.

Evdokimova, A. Y., Terekhov, V. I, and Matveev, S. M. (2020). Forestry assessment of 35-year-olds scots pine crops that are susceptible to recreational effect. Plodovodstvo Semenovodstvo Introduktsiya Drevesnykh Rasteniy 23, 38-42.

Forbes, B. C., Fauria, M. M., and Zetterberg, P. (2010). Russian Arctic warming and 'greening' are closely tracked by tundra shrub willows. Glob. Chang. Biol. 16, 1542-1554. doi: 10.1111/j.1365-2486.2009.02047.x

Grabenko, E. A., and Solomina, O. N. (2018). Influence of climate fluctuations on the width of the rings of Caucasian fir (Abies Nordmanniana) in the beechfir forests of the Western Caucasus. Proc. Caucasian State Nat. Biosph. Res. 23, 34-40.

Graybill, D. A., and Shiyatov, S. G. (1988). “A 1009 year tree-ring reconstruction of mean June-July temperature deviations in the polar Urals," in Air pollution effects on vegetation, including forest ecosystems: proceedings of the second USUSSR Symposium, eds R. D. Noble, J. L. Martin, and K.F. Jensen (Corvallis, OR: Northeastern Forest Experiment Station), 37-42. 
Helama, S., Huhtamaa, H., Verkasalo, E., and Läänelaid, A. (2017). Something old, something new, something borrowed: new insights to human-environment interaction in medieval Novgorod inferred from tree rings. J. Archaeol. Sci. Rep. 13, 341-350. doi: 10.1016/j.jasrep.2017.04.008

Holobâcă, I. H., Pop, O., and Petrea, D. (2016). Dendroclimatic reconstruction of late summer temperatures from upper treeline sites in Greater Caucasus, Russia. Quat. Int. 415, 67-73. doi: 10.1016/j.quaint.2015.10.103

Hughes, M. K., Olchev, A., Bunn, A. G., Berner, L. T., Losleben, M., and Novenko, E. (2019). Different climate responses of spruce and pine growth in Northern European Russia. Dendrochronologia 56:125601. doi: 10.1016/j.dendro.2019. 05.005

Karpukhin, A. A. (2009). Absolute dendrochronological scales of archaeological sites in European Russia. Archaeol. Ethnol. Anthropol. Eurasia 37, 62-70. doi: 10.1016/j.aeae.2009.05.007

Karpukhin, A. A., Khasanov, B. F., Krenke, N. A., Pevzner, M. M., and Solovyeva, L. N. (2020). Dendrochronological and radiocarbon dating of Eastern European oak (1074-1306). Russian Archaeology 1, 9-21. doi: 10.31857/ S086960630008250-4

Karpukhin, A. A., and Matskovsky, V. V. (2014). Absolute generalized dendrochronological scale of the Sheksna and Sukhona river basins (10852009) (Absolyutnaya generalizirovannaya dendrokhronologicheskaya shkala basseynov rek Sheksna i Sukhona (1085-2009 gg.). Russ. Archeol. 2, 76-87.

Karpukhin, A. A., Matskovsky, V. V., and Solovyeva, L. N. (2019). Tree-ring chronologies of wooden architecture in Karelia. KSIA 257, 393-407.

Kasatkina, E. A., Shumilov, O. I., and Timonen, M. (2019). Solar activity imprints in tree ring-data from northwestern Russia. J. Atmos. Sol. Terr. Phys. 193:105075. doi: 10.1016/j.jastp.2019.105075

Kasatkina, E. A., Shumilov, O. I., Timonen, M., and Kanatjev, A. G. (2013). Consequences of powerful volcanic eruptions according to dendrochronological data. Izv. Atmos. Ocean. Phys. 49, 432-438. doi: 10.1134/S0001433813040063

Khakimulina, T., Fraver, S., and Drobyshev, I. (2016). Mixed-severity natural disturbance regime dominates in an old-growth Norway spruce forest of northwest Russia. J. Veget. Sci. 27, 400-413. doi: 10.1111/jvs.12351

Kharitonova, T. I., and Novenko, E. Y. (2019). Origin and frequency of surface wildfires in south-eastern Meschera lowland (according to dendrochronological data). Vestnik Moskovskogo Univ. Seriya 5 Geografiya 4, 53-62.

Khasanov, B. F. (2011). Indication of extreme weather events on the wood anatomy of oak trees (Quercus robur L.) from the central European Russia (Indikatsiya anomal'nykh pogodnykh yavleniy po dannym izucheniya drevesiny duba chereshchatogo (Quercus robur L.) iz sredney polosy Yevropeyskoy Rossii). J. Sib. Fed. Univ. Ser. Biol. 4, 355-367. doi: 10.17516/1997-1389-0159

Khasanov, B. F. (2013). Severe winter rings of oak trees (Quercus robur L.) from central European Russia. Int. J. Biometeorol. 57, 835-843. doi: 10.1007/s00484012-0611-1

Khasanov, B. F., Karpukhin, A. A., Krenke, N. A., Pevzner, M. M., Tarabardina, O. A., Vasyukov, D. D., et al. (2021a). Long oak tree-ring chronologies from Central Russia and their potential for dating. Tree Ring Res. 77, 53-62. doi: 10.3959/TRR2020-5

Khasanov, B. F., Knysh, N. V., Lukin, V. V., Nakamura, T., Okuno, M., Tyers, I., et al. (2021b). Subfossil oak trees from the Zapadnaya Dvina (Daugava) River. Dendrochronologia (in press).

Khasanov, B. F., and Sandlersky, R. B. (2018). Does insect induced defoliation affect anatomical structure of oak wood? Dendrochronologia 51, 66-75. doi: 10.1016/j.dendro.2018.08.003

Kilpinen, S. (2018). Variability and Mixed-Severity Disturbances Characterize Unmanaged Southern Boreal Forests in Russian Karelia. Ph.D. thesis. Helsinki: Helsinki University.

Kolchin, B. A. (1962). Dendrochronology of Novgorod. (Dendrokhronologiya Novgoroda). Sov. Archeol. 1, 113-139.

Kolchin, B. A., and Chernykh, N. B. (1977). Dendrochronology of Eastern Europe (Dendrokhronologiya Vostochnoy Yevropy). Moscow: Science Publishing Group.

Kononov, Y. M., Friedrich, M., and Boettger, T. (2009). Regional summer temperature reconstruction in the Khibiny Low Mountains (Kola Peninsula, NW Russia) by means of tree-ring width during the last four centuries. Arct. Antarct. Alp. Res. 41, 460-468. doi: 10.1657/1938-4246-41.4.460

Kuznetsova, V. V. (2020). Hydrometeorological reconstructions in the Volga region based on dendrochronological data. (Gidrometeorologicheskiye rekonstruktsii $v$ Povolzhye po dendrokhronologicheskim dannym). Ph.D. thesis. Moscow: Institute of Geography RAS.

Lange, J., Buras, A., Cruz-García, R., Gurskaya, M., Jalkanen, R., Kukarskih, V., et al. (2018). Climate Regimes Override Micro-Site Effects on the Summer Temperature Signal of Scots Pine at Its Northern Distribution Limits. Front. Plant Sci. 9:1597. doi: 10.3389/fpls.2018.01597

Ljungqvist, F. C., Krusic, P. J., Brattström, G., and Sundqvist, H. S. (2012). Northern Hemisphere temperature patterns in the last 12 centuries. Clim. Past 8, 227-249. doi: 10.5194/cp-8-227-2012

Lopatin, E., Kolstrom, T., and Spiecker, H. (2007). Impact of climate change on radial growth of Siberian Spruce and Scots Pine in North-Western Russia. Forest@ 4, 28-41.

Lopatin, E., Kolström, T., and Spiecker, H. (2008). Long-term trends in radial growth of Siberian spruce and Scots pine in Komi Republic (northwestern Russia). Bor. Environ. Rese. 13, 539-552.

Lovelius, N. V. (1979). Variability of tree growth (Izmenchivost' prirosta dereviev). Saint-Petersburg: Nauka.

Luterbacher, J., Werner, J. P., Smerdon, J. E., Fernández-Donado, L., GonzálezRouco, F. J., Barriopedro, D., et al. (2016). European summer temperatures since Roman times. Environ. Res. Lett. 11:024001. doi: 10.1088/1748-9326/11/ $2 / 024001$

Matskovsky, V., Dolgova, E., Lomakin, N., and Matveev, S. (2016b). Dendroclimatology and historical climatology of Voronezh region, European Russia, since 1790s. Int. J. Climatol. 37, 3057-3066. doi: 10.1002/joc.4896

Matskovsky, V., Dolgikh, A., and Voronin, K. (2016a). Combined dendrochronological and radiocarbon dating of three Russian icons from the 15th-17th century. Dendrochronologia 39, 60-68. doi: 10.1016/j.dendro.2015.10.002

Matskovsky, V., Gadiev, U., Dolgikh, A., Cherkinsky, A., Polumieva, P., Panov, V., et al. (2019). Radiocarbon Dating of Medieval Buildings in the Mountainous Part of Ingushetia (Northern Caucasus, Russia). Radiocarbon 3, 777-797. doi: 10.1017/RDC.2019.33

Matskovsky, V. V. (2013). Climatic signal in tree-ring width of conifers in the north and center of European Russia. Moscow: GEOS.

Matskovsky, V. V. (2014). "Dendrochronological study of the "Chapel of Cyril" in the Kirillo-Belozersky monastery (Dendrokhronologicheskoye issledovaniye "Chasovni Kirilla» v Kirillo-Belozerskom monastyre)," in Prepodobnyy Sergiy, "rodom rostovets.»: materialy konferentsii, (Rostov: GMZ Rostovskiy Kreml), 305-313.

Matskovsky, V. V. (2016). Climatic signal in tree-ring width chronologies of conifers in European Russia. Int. J. Climatol. 36, 3398-3406. doi: 10.1002/joc. 4563

Matskovsky, V. V., Solomina, O. N., and Bushueva, I. S. (2013). "Dendrochronology of the Solovetsky Islands," in In Solovetsky Collection, ed. S. G. Rubtsov (Arkhangelsk: Arkhangelsk State Medical Academy), 41-58.

Matveev, S., Timashchuk, D., and Matskovsky, V. (2019). The intensity of the climatic signal in the dynamics of the increment of Scots pine (Pinus silvestris L.) of the Khrenovskii forest (Voronezh region, Russia). IOP Conf. Ser. Earth Environ. Sci. 226:012017. doi: 10.1088/1755-1315/226/1/012017

Matveev, S., Tishin, D., Maximchuk, P., and Zhuravleva, I. (2020). Seasonal radial growth dynamics of Scots pine (Pinus silvestris L.) in Voronezh region (Russia). IOP Conf. Ser. Earth Environ. Sci. 595:012044. doi: 10.1088/1755-1315/595/1/ 012044

Matveev, S. M., and Akulov, V. V. (2012). Condition dynamics of Scots pine (Pinus sylvestris L.) along suburban highways of Voronezh city in 1991-2007. Tomsk State Univ. J. 364, 212-218.

Matveev, S. M., and Lykov, I. V. (2019). "Analysis of the impact of air pollution by vehicles (highway M-4 "Don") on Scots pine forests in the suburban area of Voronezh (Analiz vliyaniya zagryazneniya atmosfery avtotransportom (avtotrassa M-4 "Don") na lesnyye kul'tury sosny obyknovennoy v prigorodnoy zone g. Voronezha)," in Environmental problems and the ecological situation in European Russia and adjacent territories (Problemy prirodopol'zovaniya $i$ ekologicheskaya situatsiya $v$ Yevropeyskoy Rossii $i$ na sopredel'nykh territoriyakh), ed. M. A. Polshina (Belgorod: Izd. Dom Belgorod), 154-157.

Matveev, S. M., Matveeva, S. V., and Shurygin, Y. N. (2012). Recurrence of severe droughts and long-term of radial increment in the Usman and Khrenovoe forests in the Voronezh region. J. SFU. Biol. 5, 27-42. doi: 10.17516/1997-13890150 
Mergelov, N., Petrov, D., Zazovskaya, E., Dolgikh, A., Golyeva, A., Matskovsky, V., et al. (2020). Soils in Karst Sinkholes Record the Holocene History of Local Forest Fires at the North of European Russia. Forests 11:1268. doi: 10.3390/ f11121268

Molchanov, A. A. (1976). Dendroclimatic bases of weather forecasts (Dendroklimaticheskie osnovy prognoza pogody). Moscow: Nauka.

PAGES 2k Consortium (2013). Continental-scale temperature variability during the past two millennia. Nat. Geosci. 6, 339-346. doi: 10.1038/ngeo1797

Panyushkina, I. P., Karpukhin, A. A., and Engovatova, A. V. (2016). Moisture record of the Upper Volga catchment between AD 1430 and 1600 supported by a $\delta 13 \mathrm{C}$ tree-ring chronology of archaeological pine timbers. Dendrochronologia 39, 24-31. doi: 10.1016/j.dendro.2016.02.002

Petrov, M. I., and Tarabardina, O. A. (2020). Novgorod in 10th-14th centuries: city area evolution. Arkheologicheskiye Vesti 28, 134-151. doi: 10.31600/1817-69762020-28-134-151

Pushin, A. V., Chernavskaya, M. M., and Chernykh, N. B. (2000). Climatic extremes and growth anomalies of wood in 16-19 centuries in the north of the Russian. Russ. Archaeol. 4, 86-99.

Rumyantsev, D. E. (2010). History And Methodology Of Forestry Dendrochronology (Istoriya i metodologiya lesovodstvennoy dendrokhronologii). Moscow: MGUL.

Ryzhkova, N., Pinto, G., Kryshen', A., Bergeron, Y., Ols, C., and Drobyshev, I. (2020). Multi-century reconstruction suggests complex interactions of climate and human controls of forest fire activity in a Karelian boreal landscape, North-West Russia. For. Ecol. Manage. 459:117770. doi: 10.1016/j.foreco.2019. 117770

Schweingruber, F. H., and Briffa, K. R. (1996). "Tree-ring density networks for climate reconstruction," in Climatic variations and forcing mechanisms of the last 2000 years, eds P. D. Jones, R. S. Bradley, and J. Jouzel (Berlin, Heidelberg: Springer), 46-66. doi: 10.1007/978-3-642-61113-1_3

Semenyak, N. S., Dolgova, E. A., and Matskovsky, V. V. (2021). Use of dendrochronological analysis for dating historical sites (Ispol'zovaniye dendrokhronologicheskogo analiza dlya datirovaniya istoricheskikh ob'yektov)" in New materials and methods of archaeological research (Novyye materialy i metody arkheologicheskogo issledovaniya), eds A. O. Gliko, A. A. Baryakh, K. V. Lobanov, and I. N. Bolotov (Moscow: IARAN), 165-167.

Shumilov, O. I., Kasatkina, E. A., Mielikainen, K., Timonen, M., and Kanatjev, A. G. (2011). Palaeovolcanos, Solar activity and pine tree-rings from the Kola Peninsula (northwestern Russia) over the last 560 years. Int. J. Env. Res. 5, $855-864$.

Shvedov, F. N. (1892). Tree as a chronicle of droughts (Derevo kak letopis' zasukh). Meteorol. Courrier (Vestnik) n5,

Sochová, I., Koláŕ, T., and Rybníček, M. (2021). A Review of Oak Dendrochronology in Eastern Europe. Tree Ring Res. 77, 10-19. doi: 10.3959/TRR2020-2

Solomina, O., Bushueva, I., Dolgova, E., Jomelli, V., Alexandrin, M., Mikhalenko, V., et al. (2016). Glacier variations in the Northern Caucasus compared to climatic reconstructions over the past millennium. Glob. Planet. Change 140, 28-58. doi: 10.1016/j.gloplacha.2016.02.008

Solomina, O., Dolgova, E., and Maximova, O. (2012). Tree-ring based hydrometeorological reconstructions in Crimea, Caucasus and Tien-Shan. Moscow, Saint-Petersburg: Nestor-Istoriya.

Solomina, O. N. (1999). Mountain Glaciation Of Northern Eurasia In The Holocene. Moscow: Nauchniy Mir.

Solomina, O. N., Bushueva, I. S., Dolgova, E. A., Zolotokrylin, A. N., Kuznetsova, V. V., Kuznetsova, T. O., et al. (2017). Droughts of the East European plain according to hydrometeorological and tree-ring data. Moscow, Saint-Petersburg: Nestor-Isrotriya.

Solomina, O. N., Bushueva, I. S., Volodicheva, N. A., and Dolgova, E. A. (2021). Age of moraines of the Bolshoy Azau Glacier in the upper course of the Baksan River valley according to dendrochronological data. Led I Sneg 61, 271-290.

Solomina, O. N., Matskovskii, V. V., and Zhukov, R. S. (2011). The Vologda and Solovki Dendrochronological "Chronicles" as a Source of Information about the Climate Conditions of the Last Millennium. Dokl. Earth Sci. 439, 1104-1109. doi: 10.1134/S1028334X11080071
Tarabardina, O. A. (2009). Environment and human behavior in northern dendrochronological studies of medieval Novgorod: (Based on the Findings of Archaeological Excavations 1991-2006). Archaeol. Ethnol. Anthropol. Eurasia 37, 77-84. doi: 10.1016/j.aeae.2009.05.009

Tarabardina, O. A., Karpukhin, A. A., Matskovsky, V. V., and Solovyeva, L. N. (2016). Dendrochronology of medieval Novgorod: analysis of chronological and quantitative distribution of dendrochronological dates of wood samples. KSIA 245, 22-35.

Tishin, D., Fardeeva, M., Chizhikova, N., and Rizatdinov, R. (2018). Acclimation of Juglans mandshurica Maxim. and Phellodendron amurense Rupr. in the Middle Volga region. IOP Conf. Ser. Earth Environ. Sci. 107:012094. doi: 10.1088/1755$1315 / 107 / 1 / 012094$

Tishin, D. V. (2006). The influence of natural and climatic factors on the radial growth of trees in the middle Volga region (Vliyaniye prirodno-klimaticheskikh faktorov na radial'nyy prirost derev'ye vsrednego Povolzhya). Ph.D. thesis. Kazan: Institute of Ecology of Natural Systems of the Academy of Sciences of the Republic of Tatarstan.

Tishin, D. V., and Chizhikova, N. A. (2011). Dendroclimatic investigations of Pinus sylvestris L. on Keretsky Archipelago Islands, the White Sea. J. SFU. Biol. 4, 378-388. doi: 10.17516/1997-1389-0161

Tishin, D. V., Chizhikova, N. A., Zhuravleva, I. V., and Chugunov, R. G. (2016). Xylogenesis of Pinus sylvestris L. growing in the northern island ecosystems. Lesotekhnicheskiy zhurnal 4, 89-97. doi: 10.12737/23439

Tishin, D. V., Chizhikova, N. A., Zhuravleva, I. V., and Iskandirov, P. Y. (2019). Pine xylogenesisin contrasting hydrothermal conditions (Ksilogenez sosny v kontrastnykh gidrotermicheskikh usloviyakh)," In Transformation of ecosystems under the influence of natural and anthropogenic factors (Transformatsiya ekosistem pod vozdeystviyem prirodnykh i antropogennykh faktorov), ed. T. Ya. Ashikhmina (Kirov: VyatGU), 78-81.

Turmanina, V. I. (1971). "Perspectives of applying phytoindicational methods in glaciology (Perspektivy primenenija fitoindikacionnyh metodov v gljaciologii)," in Climate change estimation using phytoindication (Otsenka izmeneniya klimata s pomoshch'yu fitoindikatsii), ed. G. K. Tushinsky (Moscow: Izd-vo MGU).

Turmanina, V. I. (1988). "Climate fluctuations in the past millennium based on phytoindication methods (Otsenka klimaticheskikh izmeneniy fitoindikatsionnimi metodami za poslednee tysyacheletie)," in Phytoindication Methods in Glaciology (Fitoindikacionnye metody $v$ gljacilogii), ed. G. K. Tushinsky (Leningrad: Gidrometeoizdat).

Voronin, K., Dolgikh, A., Matskovsky, V., Cherkinsky, A., Skripkin, V., and Alexandrovskiy, A. (2015). Comparative dendrochronological and 14C dating of 15 th century Russian icon. Radiocarbon 57, 173-182. doi: 10.2458/azu_rc. 57.17467

Yermokhin, M. (2012). The tree-ring chronology of Scots pine (Pinus sylvestris L.) from the Nesvizh castle XVI-XIX cc. in central Belarus. Dendrochronologia 30, 69-72. doi: 10.1016/j.dendro.2011.01.012

Conflict of Interest: The authors declare that the research was conducted in the absence of any commercial or financial relationships that could be construed as a potential conflict of interest.

Publisher's Note: All claims expressed in this article are solely those of the authors and do not necessarily represent those of their affiliated organizations, or those of the publisher, the editors and the reviewers. Any product that may be evaluated in this article, or claim that may be made by its manufacturer, is not guaranteed or endorsed by the publisher.

Copyright (c) 2021 Solomina and Matskovsky. This is an open-access article distributed under the terms of the Creative Commons Attribution License (CC BY). The use, distribution or reproduction in other forums is permitted, provided the original author(s) and the copyright owner(s) are credited and that the original publication in this journal is cited, in accordance with accepted academic practice. No use, distribution or reproduction is permitted which does not comply with these terms. 